Rafae Michatowski ${ }^{1}$

\title{
Przeciwdziałanie nadmiernej koncentracji nieruchomości rolnych przy sprzedaży gruntów z Zasobu Własności Rolnej Skarbu Państwa
}

Ograniczenie obszarowe funkcjonujące $\mathrm{w}$ obrębie regulacji prawnej sprzedaży nieruchomości z Zasobu Własności Rolnej Skarbu Państwa wyznacza art. 28a ustawy z dnia 19.10.1991 r. o gospodarowaniu nieruchomościami rolnymi Skarbu Państwa. ${ }^{2}$ Stanowi on w ust. 1, że sprzedaż nieruchomości rolnej przez Agencję Nieruchomości Rolnych może nastąpić, jeżeli w wyniku tej sprzedaży łączna powierzchnia użytków rolnych stanowiących własność nabywcy nie przekroczy 500 ha. Jest to rozwiązanie o ściśle antykoncentracyjnym charakterze, które koresponduje z treścią art. 1 pkt 2 ustawy z dnia 11.04.2003 r. o kształtowaniu ustroju rolnego. ${ }^{3}$

Ustalając, czy nabycie nieruchomości przez dany podmiot spowoduje przekroczenie wskazanego w art. 28a ust. 1 maksimum obszarowego, czyni się to, abstrahując od tego, czy użytki rolne będące jego własnością stanowią jedną zorganizowaną całość gospodarczą. W tym też (a więc oderwaniu wyznaczonego przez prawodawcę limitu obszarowego od kwestii, czy wszystkie użytki stanowią całość gospodarczą) tkwi podobieństwo normy obszarowej przewidzianej przez art. 28a ust. 1 u.g.n.r. do normy 300 ha użytków rolnych przewidzianej w definicji ustawowej rolnika indywidualnego zawartej $\mathrm{w}$ art. 6 ust. 1 u.k.u.r. ${ }^{4}$

Ograniczenie obszarowe $\mathrm{z}$ art. 28a ust. 1 u.g.n.r. nie jest związane jedynie z jakimś jednym, szczególnym trybem zawarcia umowy sprzedaży. Dotyczy ono zarówno umów sprzedaży zawieranych w trybie przetargowym, jak i umów zawieranych z pominięciem tego trybu, zwłaszcza w przypadku określonym w art. 29 ust. 1 u.g.n.r. Ograniczenie zawarte $w$ art. 28 a ust. 1 u.g.n.r. nie znajduje jednak zastosowania $\mathrm{w}$ przypadku procedury przetargu ograniczonego adresowanego do osób fizycznych, które mają powiększyć gospodarstwo rodzinne (art. 29 ust. 3b pkt 1

Uniwersytet w Białymstoku.

Dz.U. z 2012 r. poz. 1187; dalej: u.g.n.r.

Dz.U. z 2012 r. poz. 803, dalej: u.k.u.r.

W kwestii normy obszarowej określonej w przepisach u.k.u.r. zob. Z. Truszkiewicz, Przeniesienie własności nieruchomości rolnej według ustawy o kształtowaniu ustroju rolnego (cz. 2), „Rejent” 2003, nr 11, s. 116-117. 
u.g.n.r.). Jest tak, ponieważ w powyższym przypadku osoby powiększające gospodarstwo rodzinne muszą spełnić kryteria wymagane przez przepisy u.k.u.r., w tym zadośćuczynić przesłankom wymaganym od rolnika indywidualnego (art. 6 ust. 1 u.k.u.r.). Jak wyżej wspomniano, przepis ten ustanawia normę 300 ha użytków rolnych, której przekroczenie pozbawia nabywcę statusu rolnika indywidualnego i tym samym powiększanemu bądź nowo tworzonemu gospodarstwu nie można przypisać wówczas statusu gospodarstwa rodzinnego. Dokonanie w takim przypadku sprzedaży w trybie przetargu ograniczonego z naruszeniem pułapów obszarowych określonych w u.k.u.r. byłoby jednocześnie naruszeniem ustawowych przesłanek dopuszczalności zastosowania tego trybu sprzedaży i co za tym idzie - pociągałoby za sobą konsekwencje w postaci nieważności zawartej w wyniku jego przeprowadzenia umowy.

Ustawodawca nie wskazuje expressis verbis w treści art. 28a u.g.n.r. konsekwencji naruszenia zakazu określonego w jego ust. 1. Dokonywane w piśmiennictwie próby określenia sankcji za uchybienie wskazanemu wyżej zakazowi wymagają, moim zdaniem, pewnej korekty. Zaznaczam przy tym, że wyrażone w doktrynie w tej kwestii opinie uznaję za aktualne, pomimo że zostały sformułowane przed nowelizacją u.g.n.r. i dodaniem ust. 4 w art. 28a, mówiącego o odpowiedzialności karnej za złożenie fałszywego oświadczenia o powierzchni użytków rolnych przez nabywcę nieruchomości rolnej. ${ }^{5}$ Jest tak dlatego, że - moim zdaniem - ustanowienie przez prawodawcę konsekwencji określonych w art. 28a ust. 4 nie determinuje automatycznie konieczności przyjęcia jakiegoś konkretnego następstwa naruszenia zakazu określonego w ust. 1 tego artykułu. Jego określenie, w braku wyraźnego stanowiska prawodawcy, powinno się rozstrzygać, mając na uwadze cel regulacji, w tym wartości, których urzeczywistnieniu ma ona służyć.

Z jednej strony R. Sztyk wprost stwierdza, że naruszenie tego zakazu nie powoduje nieważności czynności prawnej. ${ }^{6}$ Także z uwag sformułowanych przez J. Mikołajczyk zdaje się wynikać, iż przyjmuje ona brak jakiejkolwiek sankcji za naruszenie tego zakazu. ${ }^{7} \mathrm{Z}$ drugiej zaś strony A. Lichorowicz wskazuje tu na sankcję nieważności. Jako podstawę wskazuje art. 9 ust. 1 u.k.u.r., co uzasadnia tym, że

Zob. ustawę z dnia 16.09.2011 r. o zmianie ustawy o gospodarowaniu nieruchomościami rolnymi Skarbu Państwa oraz o zmianie niektórych innych ustaw (Dz.U. Nr 233, poz. 1382).

6 R. Sztyk, Podstawowe zasady kształtowania ustroju rolnego, „Rejent” 2003, nr 5, s. 39.

7 J. Mikołajczyk, Uwagi na tle ustawy o kształtowaniu ustroju rolnego, „Studia Prawno-Ekonomiczne” 2004, t. 69 s. 121-122. Autorka, w toku prowadzonych rozważań najpierw pisze o normie obszarowej 300 ha użytków rolnych określonej w art. 5 ust. 2 u.k.u.r., potem wspomina o normie obszarowej określonej w art. 28a ust. 1 u.g.n.r. dodanym przez art. 12 pkt 10 u.k.u.r. Następnie stwierdza: „[...] ustawa o kształtowaniu ustroju rolnego nie ingeruje w stan zastany. Oznacza to, że istniejące obecnie gospodarstwa rolne o powierzchni ponad 300 hektarów i ponad 500 hektarów będą mogły istnieć nadal. Odnotować w tym miejscu należy również, że norma obszarowa odnosi się do wszystkich nabywców nieruchomości rolnych zarówno krajowych, jak i zagranicznych, a jej przekroczenie nie powoduje nieważności czynności prawnej”. Jak wynika z przytoczonego fragmentu, Autorka, określając konsekwencje przekroczenia normy obszarowej nie wyszczególnia wyraźnie, że pisze o normie obszarowej wskazanej w art. 28a ust. 1 u.g.n.r., jednak wydaje się, że jej opinia o braku sankcji nieważności na wypadek przekroczenia normy obszarowej odnosi się do norm zawartych zarówno w u.k.u.r., jak i w u.g.n.r. 
art. 28a u.g.n.r. został dodany do ug.n.r. przez art. 12 pkt 10 u.k.u.r. ${ }^{8}$ Zgodnie zaś z brzmieniem art. 9 ust. 1 u.k.u.r. czynność prawna dokonana niezgodnie z przepisami ustawy lub bez zawiadomienia uprawnionego do prawa pierwokupu lub bez zawiadomienia Agencji, w przypadku określonym w art. 4 ust. 1, jest nieważna.

Obydwa przywołane poglądy mogą wzbudzać pewne wątpliwości. Nie wydaje się, aby - jak stwierdza A. Lichorowicz - można było odnieść postanowienia art. 9 ust. 1 u.k.u.r. do konsekwencji naruszenia art. 28a ust. 1 u.g.n.r. Art. 9 ust. 1 u.k.u.r. określa jedynie konsekwencje naruszenia przepisów tej ustawy dotyczących prawa pierwokupu i nabycia. Nie można powiedzieć, że art. 28a to „przepis ustawy” w sensie, o który chodzi w art. 9 ust. 1 u.k.u.r. Chodzi tam o określenie konsekwencji naruszenia „własnych” przepisów u.k.u.r., a nie przepisów innych aktów prawnych zmienionych czy dodanych przez u.k.u.r.

Jeśli chodzi o pogląd reprezentowany przez R. Sztyka oraz J. Mikołajczyk, to wydaje się, że ma on być uprawomocniony przez to, że ustawodawca nie przewidział konsekwencji naruszenia postanowień art. 28a ust. 1 u.g.n.r. w odrębnym przepisie wyraźnie odnoszącym się do sytuacji w nim określonych. Należałoby jednak zwrócić uwagę na to, że jego uzasadnienie celowościowe w części jest takie jak i instrumentów prawnych przewidzianych przez u.k.u.r. - jak już była o tym mowa. Zgodnie z art. 1 pkt 2 u.k.u.r. ustawa ma na celu przeciwdziałanie nadmiernej koncentracji nieruchomości rolnych. Między innymi ten cel, w świetle u.k.u.r., uprawomocnia przewidzianą $\mathrm{w}$ art. 9 ust. 1 sankcję nieważności czynności prawnej. To uzasadnia stwierdzenie, że uzasadnienie aksjologiczne środków prawnych zawartych $\mathrm{w}$ przepisach u.k.u.r., obwarowanych przewidzianą przez art. 9 ust. 1 u.k.u.r. sankcją nieważności oraz zakazu z art. 28a u.g.n.r., jest częściowo ${ }^{9}$ tożsame. Mówienie więc w tym kontekście o braku jakiejkolwiek sankcji na wypadek naruszenia art. 28a zakłada aksjologiczną niekonsekwencję prawodawcy. Jednak to jeszcze za mało, aby od razu przyjąć sankcję nieważności w tym przypadku. Dla jej uzasadnienia można sięgnąć do innych przepisów regulujących tryb sprzedaży gruntów Zasobu. Zadośćuczynienie wymogowi z art. 28a ust. 1 jest też wprost ustanowione jako przesłanka zawarcia umowy sprzedaży, skoro art. 29 ust. $3 \mathrm{~g}$ pkt 3 u.g.n.r. stanowi, że zawarcie umowy jest niemożliwe w razie niespełnienia tego wymogu. Poza tym stanowienie przepisów wyrażających normy pozbawione sankcji nie jest typowym rozwiązaniem $w$ ramach regulacji obrotu nieruchomościami skarbowymi. Zaznaczyć trzeba również, że zwolennicy poglądu o braku sankcji za naruszenie przepisu art. 28a ust. 1 nie podają przesłanek, które prowadzą ich do przyjęcia tego stanowiska.

8 A. Lichorowicz, Instrumenty oddziaływania na strukturę gruntową Polski w ustawie z dnia 11 kwietnia 2003 r. o kształtowaniu ustroju rolnego, „Kwartalnik Prawa Prywatnego” 2004, nr 2, s. 393.

9 Oprócz tego celem u.k.u.r. jest poprawa struktury obszarowej gospodarstw rodzinnych oraz zapewnienie prowadzenia działalności rolniczej przez osoby o odpowiednich kwalifikacjach (art. 1 pkt 1 i 3 u.k.u.r.). 
Wskazane argumenty wymagają jednak uzupełnienia przez wskazanie, który przepis może zostać uznany za podstawę zastosowania sankcji nieważności na wypadek naruszenia art. 28a ust. 1. Powyżej uzasadniłem, dlaczego nie może to być art. 9 ust. 1 stosowany wprost. Nie uważam również, aby można było stosować go w drodze analogii - jest to regulacja szczególna, powiązana ściśle z prawem pierwokupu i prawem nabycia z u.k.u.r. Stąd rozszerzanie jego zakresu zastosowania ponad okoliczności wyraźnie w nim przewidziane nie wydaje się być dopuszczalne. ${ }^{10}$

Na tle brzmienia art. 28a ust. 1 należy odróżnić dwie sytuacje. Po pierwsze, wynika z niego bezwzględny zakaz zawierania umów sprzedaży nieruchomości Zasobu, w których przedmiot świadczenia sprzedającego obejmuje więcej niż 500 ha użytków rolnych. Przepisy u.g.n.r. nie przewidują żadnych okoliczności uchylających ten wymóg. Stąd zawarcie umowy sprzedaży nieruchomości Zasobu o powierzchni użytków rolnych przekraczających 500 ha w konsekwencji prowadziłoby do nieważności czynności prawnej z powodu sprzeczności treści czynności prawnej z ustawą (art. $58 \S 1 \mathrm{kc}$.). Po drugie, ustawodawca zakazuje zawierania umów sprzedaży, w wyniku których nabywca stanie się właścicielem użytków rolnych powyżej pułapu 500 ha. W tym przypadku zakazane działanie należy rozpatrywać w konkretnych okolicznościach. Innymi słowy - sprzedaż przykładowo nieruchomości o pow. 200 ha użytków rolnych raz będzie, a innym razem nie będzie zakazana - wszystko zależy od tego, ilu użytków rolnych właścicielem jest już kupujący. Zakaz ten dotyczy, ściśle rzecz ujmując, osiągania określonego rezultatu w majątku nabywcy poprzez zawarcie umowy - zakazana treść czynności prawnej wskazywana jest pośrednio poprzez ten rezultat. Stąd w tym dość nietypowym przypadku należałoby, moim zdaniem, mówić o stosowaniu art. $58 \S 1 \mathrm{kc}$. w drodze analogii. Sama dopuszczalność analogicznego stosowania tego przepisu w analizowanej sytuacji nie powinna zaś budzić większych oporów. Po pierwsze, przyjęcie sankcji nieważności ma należyte, znajdujące źródło w wartościach preferowanych przez prawodawcę uzasadnienie, co zostało wykazane powyżej. Po drugie, jego zastosowanie do innych aspektów niż treść (lub cel) czynności prawnej została już dopuszczona w doktrynie i orzecznictwie, a to w zakresie określenia skutków naruszenia obligatoryjnej procedury przetargowej. ${ }^{11}$

Do treści art. 28a ust. 1 u.g.n.r. w zakresie wskazanego tam pułapu obszarowego nawiązano w jednej z wypowiedzi doktrynalnych, formułując definicję gospodarstwa rodzinnego dla potrzeb określenia jego znaczenia w obrębie regulacji przetargu

10 Nie wspominając już o tym, że jego redakcja jest wadliwa i nawet na gruncie przepisów u.k.u.r. przysparza wiele wątpliwości interpretacyjnych; zob. A. Lichorowicz, Instrumenty oddziaływania...,s. 409 i nast.

11 Por. R. Szostak, Przetargowe sposoby ustalania nabywców nieruchomości publicznych (cz. I), „Rejent” 2006, nr 12, s. 22-23; por. też R. Trzaskowski, Granice swobody kształtowania treści i celu umów obligacyjnych. Art. 353 kc., Kraków 2005, s. 260. 
ograniczonego w u.g.n.r. przed jej zmianą dokonaną ustawą z dnia 16.09.2011 r. ${ }^{12}$ Zgodnie z art. 29 ust. 3b pkt 1 u.g.n.r., w brzmieniu przed tą zmianą, Agencja mogła zastrzec, że w przetargu mogły uczestniczyć jedynie osoby fizyczne spełniające warunki określone w przepisach o kształtowaniu ustroju rolnego zamierzające utworzyć lub powiększyć gospodarstwo rodzinne w rozumieniu tych przepisów. Zasadniczo nikt nie zgłaszał wątpliwości co do tego, że w powyższym przepisie chodziło o gospodarstwo rodzinne w rozumieniu art. 5 ust. 1 u.k.u.r. ${ }^{13} \mathrm{~W}$ doktrynie pojawiła się jednak przywołana powyżej opinia negująca ten wniosek. Ponieważ jest to jedna z nielicznych pogłębiona wypowiedź doktrynalna w powyższej materii, a w literaturze nie doczekała się dotąd komentarza, argumentacji tam przedstawionej należy poświęcić więcej uwagi. Nadmieniam, że przeprowadzona przeze mnie analiza mająca za przedmiot rozważania M Jarosiewicza wraz z wypływającymi z niej wnioskami ma za podstawę przepisy, w tym definicje zawarte w u.k.u.r. według stanu sprzed nowelizacji dokonanej ustawą dnia 16.09.2011 r.

Mając na względzie poczynione wyżej uwagi, rozważania dotyczące art. 28a stanowią dobry punkt wyjścia do analizy owego poglądu, pomimo że na skutek nowelizacji u.g.n.r. stracił on swoją aktualność. Dodatkową przesłanką uzasadniającą podjęcie rozważań tym zakresie jest to, że w tym przypadku mieliśmy do czynienia $\mathrm{z}$ zupełnie inną niż zaprezentowana przez prawodawcę $\mathrm{w}$ u.k.u.r. metodą definiowania - z odwołaniem się do pojęć niedookreślonych, w zamierzeniu sprzyjającą elastyczności regulacji prawnej, pomijającą zaś sztywnie określone kryteria eliminujące tym samym swobodę interpretatora aktu prawnego. Stąd podjęte rozważania na tle propozycji M. Jarosiewicza będą jednocześnie prowadziły do oceny możliwych sposobów konstruowania rozwiązań prawnych na potrzeby regulacji przetargowego trybu obrotu rolnymi gruntami skarbowymi. W ten sposób będzie możliwe ustosunkowanie się do dylematu, czy elastyczność tego rodzaju regulacji jest ważniejsza od jej precyzyjności, czy też odwrotnie. Ten aspekt ma w dużej mierze wymiar uniwersalny, niezależny od konkretnych rozwiązań obowiązujących w chwili obecnej.

Autor w analizach dotyczących rozumienia terminu ,gospodarstwo rodzinne" w obrębie przepisów dotyczących przetargu ograniczonego w u.g.n.r. zwraca uwagę na zawarty w art. 29 ust. 3b pkt 1 u.g.n.r. zwrot „osoby fizyczne spełniające warunki określone w przepisach o kształtowaniu ustroju rolnego, zamierzające utworzyć lub powiększyć gospodarstwo rodzinne w rozumieniu tych przepisów". Za przyjęciem innego niż w u.k.u.r. sposobu rozumienia terminu ,gospodarstwo rodzinne"

12 M. Jarosiewicz, Formy wspierania rodzinnych gospodarstw rolnych przez Agencję Nieruchomości Rolnych, „Rejent" 2009, nr 9, s. 50-85.

13 Zob. przykładowo: D. Łobos-Kotowska, Ochrona gospodarstwa rodzinnego w procesie zbywania nieruchomości rolnych przez Agencję Nieruchomości Rolnych, (w:) Własność i jej ograniczenia w prawie polskim, pod red. K. Skotnickiego i K. Winiarskiego, Częstochowa 2004, s.133, gdzie autorka pisze, że przepisy u.g.n.r. „dają ANR instrumenty ochrony gospodarstw rodzinnych w rozumieniu przepisów ustawy o kształtowaniu ustroju rolnego", [podkreśl. R.M.] m.inn. poprzez możliwość zorganizowania przetargu ograniczonego. 
przemawia już to, że ustawodawca przewidział możliwość zorganizowania przetargu ograniczonego dla osób dopiero zamierzających utworzyć gospodarstwo, bo pierwokup i prawo nabycia ANR wynikające z u.k.u.r. są wyłączone jedynie w razie powiększania już istniejącej jednostki produkcyjnej. ${ }^{14} \mathrm{~W}$ przywołanym powyżej sformułowaniu art. 29 ust. $3 \mathrm{~b}$ pkt 1, ,[k]omponent podmiotowy został [...] niejako wyciągnięty przed nawias pojęcia gospodarstwa rodzinnego, postawiony poza tym pojęciem". ${ }^{15}$ Cytowane sformułowania należy, jak mniemam, rozumieć w ten sposób, że skoro w przepisie art. 29 ust. 3b pkt 1 o przesłankach podmiotowych, o których mowa w u.k.u.r., mówi się odrębnie obok pojęcia gospodarstwa rodzinnego, to nie wchodzą one jednocześnie w skład definicji gospodarstwa rodzinnego. W innym przypadku mielibyśmy do czynienia ze zbędnym powtórzeniem. Dlatego też nie można posługiwać się na gruncie art. 29 ust. $3 \mathrm{~b}$ pkt 1 definicją gospodarstwa rodzinnego z u.k.u.r., ponieważ w u.k.u.r. przesłanki podmiotowe (w postaci pojęcia rolnika indywidualnego) są składnikiem definicji gospodarstwa rodzinnego.

M. Jarosiewicz podaje również dodatkowe argumenty przemawiające, jego zdaniem, za innym sposobem rozumienia pojęcia gospodarstwa rodzinnego w u.g.n.r. niż w u.k.u.r., odwołując się do brzmienia art. 29 ust. $3 b$ pkt 1 lit. a). Przepis wymienia potencjalnych uczestników procedury ograniczonej jako „rolników posiadających gospodarstwo rolne w gminie, na obszarze której położona jest nieruchomość wystawiana do przetargu, oraz zamierzających powiększyć to gospodarstwo". Autor stwierdza, że ,[j]edyną logiczną konstatacją jest uznanie, że na gruncie ustawy [...] pojęcie gospodarstwa rodzinnego odrywa się od wymogu zamieszkania w gminie położenia nieruchomości, stąd też niezbędnym było dodanie ppkt a) do art. 29 ust. 3b pkt 1, mimo zastrzeżenia w nim wcześniej, że traktuje on o osobach spełniających warunki z u.k.u.r." ${ }^{\prime 16}$ Dlatego też ,,[... możliwe jest zamieszkiwanie w dowolnej odległości od gospodarstwa rodzinnego, o ile tylko odległość ta nie będzie uniemożliwiała racjonalnego prowadzenia gospodarstwa". ${ }^{17}$

Autor uważa również, że treść art. 28a ust. 1 u.g.n.r. potwierdza oderwanie pojęcia gospodarstwa rodzinnego w u.g.n.r. od występującej w u.k.u.r. normy obszarowej 300 ha użytków rolnych. Jego zdaniem powyższy przepis przesądza, że gospodarstwo rodzinne w rozumieniu u.g.n.r. powinno się mieścić w granicy 500 ha użytków rolnych ,a w każdym razie może mieć powierzchnię przekraczającą 300 ha użytków rolnych". ${ }^{18}$

Podsumowując, autor konstatuje, że gospodarstwem rodzinnym w u.g.n.r. jest gospodarstwo oparte na pracy członków wspólnoty rodzinnej, jeśli chodzi o jego po-

M. Jarosiewicz, Formy wspierania..., s. 64.

Ibidem, s. 65.

Ibidem, s. 66.

Ibidem.

Ibidem, s. 69. 
wierzchnię - należy dowoływać się do specyfiki danego regionu i przeciętnej wielkości gospodarstw tam zorganizowanych. W zakresie wyznaczonym przez art. 29 ust. 3b od osób prowadzących gospodarstwo rodzinne wymaga się kwalifikacji rolniczych z u.k.u.r. a także, z zachowaniem powołanych wyżej kryteriów regionalnych, aby powierzchnia gospodarstwa nie przekroczyła 500 ha. ${ }^{19} \mathrm{~W}$ konsekwencji ,[r]ozumienie rodzinnego charakteru gospodarstwa na gruncie ustawy [...] jest zatem bliższe temu wypracowanemu na gruncie art. 23 Konstytucji niż u.k.u.r."20

Zreferowane powyżej stanowisko, jakkolwiek interesujące, wzbudza wątpliwości. Pierwszy, najistotniejszy zarzut, który można wobec niego wysunąć, ma podstawę w fakcie, że autor w swoich wywodach pominął to, że art. 29 ust. 3b stanowi o ,gospodarstwie rodzinnym w rozumieniu tych [podkr. RM] przepisów”. W kontekście brzmienia powyższego przepisu nie może ulegać najmniejszej wątpliwości, że chodzi o przepisy u.k.u.r. Taki sposób sformułowania art. 29 ust. 3b wyraźnie świadczy o tym, że mamy do czynienia $\mathrm{z}$ odesłaniem do definicji ustawowej zamieszczonej w innym akcie prawnym. ${ }^{21}$ Zaś pominięcie przy dokonywaniu wykładni przepisu jakiegoś jego fragmentu budzi poważne zastrzeżenia, mając na uwadze szeroko akceptowane zasady wykładni prawa. ${ }^{22}$

Abstrahując od powyższego, można wskazać inne niekonsekwencje w argumentacji autora. Pierwszy z powołanych przez niego argumentów - w u.k.u.r. gospodarstwo rodzinne jest chronione przy jego powiększaniu, w u.g.n.r. - gospodarstwo rodzinne może być tworzone bądź powiększane - sam w sobie niczego nie uzasadnia. Wszak gospodarstwo rodzinne w rozumieniu u.k.u.r., aby było chronione przed pierwokupem czy wykupem przez ANR, musi kiedyś powstać. Nie jest niczym zadziwiającym wprowadzenie regulacji wspierających ich tworzenie. $\mathrm{Z}$ pewnością nie ma przesłanek logicznych wynikających z samego znaczenia terminu „gospodarstwo rodzinne" w rozumieniu u.k.u.r., uzasadniających wniosek, że nie może być przedmiotem regulacji promującej tworzenie odpowiadających jego charakterystyce jednostek produkcyjnych, co potwierdza także uregulowanie przetargu ograniczonego $\mathrm{w}$ znowelizowanych przepisach u.g.n.r. Innym problemem jest zaś ocena adekwatności zastosowanych instrumentów dla realizacji założonych celów. Jest to jednak odrębne zagadnienie.

Wypada zgodzić się z autorem, że użycie przez prawodawcę w art. 29 ust. 3b pkt 1 zwrotu mówiącego o osobach spełniających przesłanki określone w u.k.u.r. zamierzających utworzyć lub powiększyć gospodarstwo rodzinne rzeczywiście było niezręczne. Zarzut ten nie jest pozbawiony podstaw, skoro w przepisie mówi się

19 Ibidem, s. 82-83.

20 Ibidem, s. 83.

21 O odesłaniach do definicji legalnych por. A. Malinowski, Redagowanie tekstu prawnego. Wybrane wskazania logiczno-językowe, Warszawa 2006, s. 60-61. 
osobno o spełnieniu przesłanek podmiotowych z u.k.u.r. a osobno obok tego wprowadza się pojęcie gospodarstwa rodzinnego - a przecież przesłanki podmiotowe i tak składają się na to pojęcie. Trzeba jednak zauważyć, że ustawodawca w jednym zdaniu jednocześnie mówi o tworzeniu i powiększaniu gospodarstw. Osobne wymienienie przesłanek podmiotowych z u.k.u.r. jest chyba spowodowane właśnie tym, że prawodawca chciał zwłaszcza podkreślić, iż dla utworzenia gospodarstwa rodzinnego trzeba spełniać pewne przesłanki, jakkolwiek wynik w postaci takiego, a nie innego brzmienia przepisu nie jest doskonały. Jednak ta w sumie niegroźna niefrasobliwość prawodawcy to zdecydowanie za mało, aby wysuwać tak kategoryczne wnioski.

Wnioski dotyczące miejsca zamieszkania rolnika prowadzącego gospodarstwo rodzinne oparte na brzmieniu art. 29 ust. 3b pkt 1 lit. a) także nie mogą zostać zaakceptowane. Zgodnie z definicją gospodarstwa rodzinnego zawartą w u.k.u.r. poszczególne nieruchomości je tworzące nie muszą być umiejscowione w jednej gminie. Nawet jednak jeśli są położone w jednej gminie, nabycie gruntów w innej gminie nie powoduje jedynie $\mathrm{z}$ tego powodu utraty przez powiększane gospodarstwo rodzinne owego przymiotu. Nowo nabywany grunt powiększa gospodarstwo rodzinne, o ile tworzy wraz z innymi gruntami zorganizowaną całość gospodarczą. Mając powyższe na uwadze, regulację art. 29 ust. $3 \mathrm{~b}$ pkt 1 lit a) stanowi zawężenie możliwości powiększania gospodarstwa rodzinnego w rozumieniu u.k.u.r. w stosunku do tego, co wynika z samej jego definicji. Innymi słowy, gdy rolnik indywidualny nabywa nieruchomość położoną w sąsiedniej gminie w stosunku do gminy, w której mieszka i w której położone są grunty jego gospodarstwa rodzinnego, to można mówić o powiększeniu tego gospodarstwa. Na gruncie regulacji art. 29 ust. $3 \mathrm{~b}$ pkt 1 lit. a) ów rolnik nie mógłby wziąć udziału w przetargu ograniczonym, mimo że obiektywnie powiększałby gospodarstwo rodzinne, ponieważ przepis węziej niż definicja z u.k.u.r. traktuje powiększenie gospodarstwa legitymujące do wzięcia udziału w przetargu. Jednak jak z tego wynika, nie ma racji M. Jarosiewicz, twierdząc, że powyższy przepis wprowadza do pojęcia gospodarstwa rodzinnego treści niemieszczące się w formule gospodarstwa rodzinnego według u.k.u.r. uzasadniające nadanie mu zupełnie odmiennego, swoistego znaczenia - ale je zawęża.

Absolutnie chybione jest powoływanie się na treść art. 28a ust. 1 u.g.n.r. dla uzasadnienia 500-hektarowej normy obszarowej gospodarstwa rodzinnego dla potrzeb u.g.n.r. Nie budzi żadnych wątpliwości, że ten przepis wprowadza górny pułap, jeśli chodzi o powierzchnię użytków rolnych, których dana osoba będzie właścicielem w konsekwencji nabycia nieruchomości z Zasobu. Jednak przepis ten, co wynika z wcześniejszych rozważań, stosuje się do wszelkich przypadków zawarcia umowy sprzedaży gruntów Zasobu - w przetargu, jak i w trybie bezprzetargowym, niezależnie od tego, czy nabywcą jest osoba fizyczna czy prawna. Nie ma żadnych przesłanek, aby twierdzić, że zawiera on uregulowanie specyficzne dla gospodarstw 
rodzinnych. Wprost przeciwnie - norma obszarowa wyznaczona art. 28a ust. 1 jest dodatkową normą obszarową nie tyle mającą na celu kształtowanie struktury gospodarstw rodzinnych, ile zapobieganie nadmiernej koncentracji gruntów w rękach jednego podmiotu, ${ }^{23}$ co ma raczej pośredni związek ze wspieraniem gospodarstw rodzinnych.

Na koniec jeszcze uwaga dotycząca zasadności posługiwania się definicją gospodarstwa rodzinnego zaproponowaną przez M. Jarosiewicza w kontekście regulacji przetargu ograniczonego. Trudno uznać, aby tak zdefiniowane przez niego gospodarstwo rodzinne było adekwatną dla tego trybu zawarcia umowy konstrukcją. Kryteria takie, jak „oparcie na pracy członków wspólnoty rodzinnej” czy też determinująca w zakresie jego powierzchni ,,specyfika danego regionu i przeciętnej wielkości gospodarstw na danym terenie" z ograniczeniem górnego pułapu do 500 ha są kryteriami niedookreślonymi, niedopasowanymi do specyfiki przetargu na nieruchomości publiczne, gdzie jednoznaczność kryteriów najlepiej sprzyja przejrzystości postępowania. Przy wszystkich zastrzeżeniach, jakie można sformułować w odniesieniu do kryteriów budujących pojęcie gospodarstwa rodzinnego według u.k.u.r., trzeba jednak przyznać, że system dowodów spełnienia poszczególnych kryteriów (zob. art. 7 u.k.u.r.) w sumie uniezależnia nabycie statusu uczestników procedury od arbitralnych, uznaniowych decyzji organizatora. Nie da się tego powiedzieć o definicji zaproponowanej przez M. Jarosiewicza. Jeśli dodatkowo weźmie się pod uwagę, że naruszenie procedury przetargowej, w tym dopuszczenie do przetargu osoby, która nie spełnia wymaganych przesłanek podmiotowych, może spowodować nieważność zawartej w wyniku przetargu umowy, to przyjęcie przy tym niedostatecznie precyzyjnej definicji gospodarstwa rodzinnego godzi $w$ zasadę bezpieczeństwa obrotu prawnego. Zwiększa się ryzyko zawierania nieważnych umów sprzedaży, gdyż może się okazać, że do procedury dopuszczona została osoba, która nie spełnia kryteriów definicyjnych z racji ich niejednoznaczności. W sumie krytykowana definicja nie mogłaby być traktowana jako podstawa stosowania norm odwołujących się do pojęcia gospodarstwa rodzinnego wg u.g.n.r. Może być jednak traktowana jako propozycja kierunkowa dla przyszłej regulacji, czyli być ujmowana jako szkielet dla bardziej precyzyjnych propozycji de lege ferenda. 
SOME REMARKS ON LEGAL REGULATION OF PREVENTION AGAINST EXCESSIVE CONCENTRATION OF AGRICULTURAL PROPERTIES IN THE SALE OF THE REAL ESTATE FROM AGRICULTURAL PROPERTY RESOURCES OF THE STATE TREASURY

Key words: tender, family farm, agricultural property.

The main purpose of this paper is to analize few selected aspects of the article 28a of the Act on management of the agricultural properties owned by the State Treasury. It is one of the legal instruments aimed at prevention against excessive concentration of agricultural properties. Important issue is to verify opinions formulated in the legal doctrine regarding to legal sanctions associated with above mentioned regulation. Author states, that violation of that legal norm causes nullity of sale contract. There are no justified reasons to assume another concept formulated in legal doctrine. Particulary, the author disagrees that it is norm without a sanction.

Paper deals also with the problem of the definition of family farm in the legal regulation of tender procedure conducted by Agricultural Property Agency. Family farm is defined in the act on formation of agrarian system and it is not necessary to create different definition exclusively for tender procedure regulation. 